\title{
The application of ceramic membranes for treating effluent water from closed-circuit fish farming
}

\author{
Małgorzata Bonisławska*, Arkadiusz Nędzarek, Arkadiusz Drost, Agnieszka Rybczyk, \\ Agnieszka Tórz
}

\author{
West Pomeranian University of Technology Szczecin, Poland \\ Department of Aquatic Sozology
}

${ }^{*}$ Corresponding author's e-mail: mbonislawska@zut.edu.pl

\begin{abstract}
Keywords: Membrane filtration, fish farming, African catfish, water treatment.
Abstract: The aim of the study was to analyze and assess the possibility of using a two-stage filtration system with ceramic membranes: a 3-tube module with $1.0 \mathrm{kDa}$ cut-off $\left(1^{\text {st }}\right.$ stage $)$ and a one-tube module with $0.45 \mathrm{kDa}$ cut-off $\left(2^{\text {nd }}\right.$ stage) for treating effluent water from a juvenile African catfish aquaculture. The study revealed that during the $1^{\text {st }}$ filtration stage of the effluent water, the highest degrees of retention were obtained with respect to: suspended solids SS (rejection coefficient $\left.\mathrm{R}_{\mathrm{I}}=100 \%\right)$, turbidity $\left(\mathrm{R}_{\mathrm{I}}=99.40 \%\right)$, total iron $\left(\mathrm{R}_{\mathrm{I}}=89.20 \%\right), \mathrm{BOD}_{5}\left(\mathrm{R}_{\mathrm{I}}=76.0 \%\right)$, nitrite nitrogen $\left(\mathrm{R}_{\mathrm{I}}=62.30 \%\right)$, and $\mathrm{COD}_{\mathrm{Cr}}\left(\mathrm{R}_{\mathrm{I}}=41.74 \%\right)$. The $2^{\text {nd }}$ filtration stage resulted in a lower reduction degree of the tested indicators in comparison to the $1^{\text {st }}$ filtration stage. At the $2^{\text {nd }}$ stage, the highest values of the rejection coefficient were noted in for the total iron content $\left(\mathrm{R}_{\mathrm{IV}}=100 \%\right), \mathrm{COD}_{\mathrm{Cr}}\left(\mathrm{R}_{\mathrm{IV}}=59.52 \% ; \mathrm{R}_{\mathrm{V}}=64.28 \%, \mathrm{R}_{\mathrm{VI}}=63.49 \%\right)$ and turbidity $\left(\mathrm{R}_{\mathrm{IV}}\right.$ and $\left.\mathrm{R}_{\mathrm{V}}=45.0 \%, \mathrm{R}_{\mathrm{VI}}=50.0 \%\right)$. The obtained results indicate that ceramic membranes (with 1.0 and $0.45 \mathrm{kDa}$ cut-offs) may be used in recirculation aquaculture systems as one of the stages of effluent water treatment.
\end{abstract}

\section{Introduction}

Fish breeding and fish farming are potential sources of surface water pollution. Effluent waters from aquaculture are characterized by a considerable percentage content of biogenic compounds originating from the leftovers of fish fodder, metabolic waste products of the fish (ammonium nitrogen, urea), as well as fertilizers used for fish pond fertilization (Rosenthal and Hilge 1992, Good et al. 2009, Davidson et al. 2013).

In order to eliminate or diminish the effect of pollution generated by fish farming on surface waters, the Recirculating Aquaculture Systems (RAS) are implemented. In RAS, the pollution is eliminated by biological treatment combined with conventional separation techniques such as sedimentation, flocculation and filtration (Schneider et al. 2007, Martins et al. 2009, Martins et al. 2010, Van Rijn 2013). The membrane filtration can be used for improving treatment systems for RAS. Both polymer and ceramic membranes can be used in filtration systems (Viadero and Noblet 2002, Yonnekawa et al. 2004, Matsushita et al. 2005, Yang et al. 2006, Gemende et al. 2008, Szmukała and Szaniawska 2009, Bonisławska et al. 2010, Kabsch-Korbutowicz and Urbanowska 2010, Harvianto et al. 2013). Polymer membranes are widely available and characterized by diversified separation capacities. However, they are less resistant to the effect of chemical, thermal and biological factors in comparison to ceramic membranes. The advantages of ceramic membranes are: their lifetime is longer compared to the polymer membranes, they may be sterilized with water vapor and cleaned using strong acids and bases, they can be stored dry after rinsing, and used membranes can be reused as ceramic material (Sondhi et al. 2003).

The aim of the study was to analyze and evaluate the possibility of using a serial two-stage filtration system with third-generation ceramic membranes: a 3-tube module with $1.0 \mathrm{kDa}$ cut-off ( $1^{\text {st }}$ stage $)$ and a one-tube module with $0.45 \mathrm{kDa}$ cut-off $\left(2^{\text {nd }}\right.$ stage $)$ for the treatment of effluent water from the aquaculture of juvenile African catfish (Clarias gariepinus Burchell, 1822) in RAS. It was assumed that at the first stage the treatment system of that kind would eliminate high-molecular substances from the effluent water, while at the second stage the reduction of substances with lower molecular masses (e.g. biogenic substances) would take place.

\section{Materials and methods}

The studies were conducted on a small-scale membrane installation realizing cross-flows, composed of: a 50-liter feed tank, a pump equipped with a stepless rotation adjustment system, a tubular membrane module, a flow heat exchanger, and a permeate tank, as well as thermometers and nanometers for temperature and pressure control (Fig. 1). 


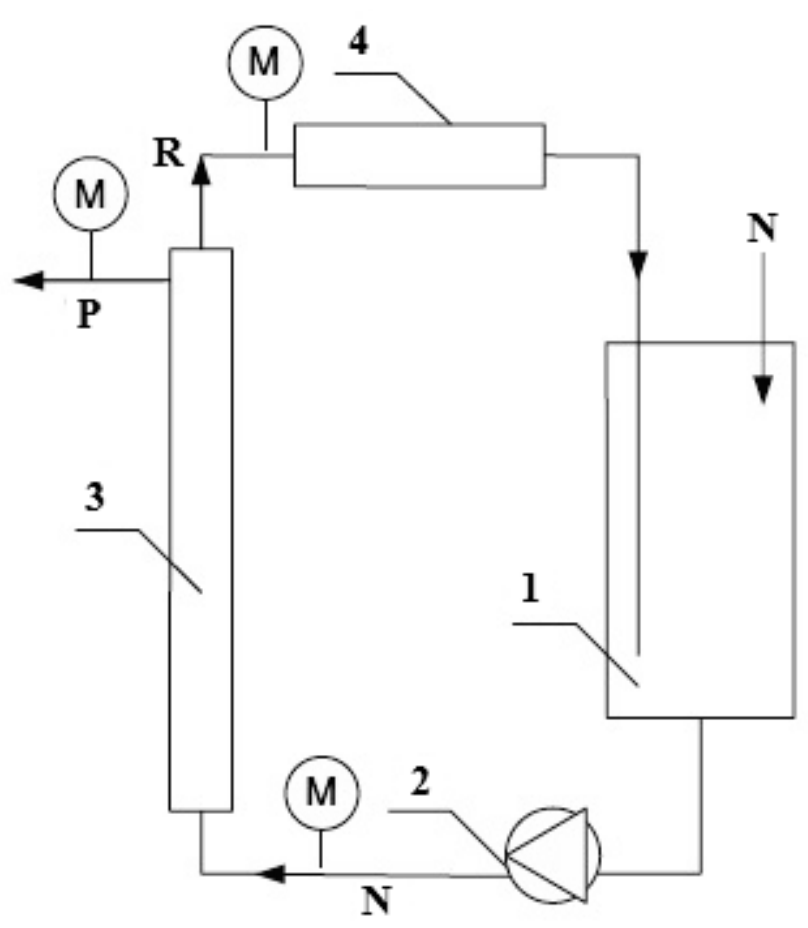

Fig. 1. Small-scale experimental rig: 1 - feed tank; 2 - pump; 3 - membrane module; 4 - radiator; $\mathrm{N}$ - feed water; $\mathrm{R}$ - retentate; $\mathrm{P}$ - permeate; $\mathrm{M}$ - manometer

Commercial tubular membranes made of $\mathrm{Al}_{2} \mathrm{O}_{3} / \mathrm{TiO}_{2} / \mathrm{ZrO}_{2}$ were used. A detailed characteristics of the membranes is given in Table 1.

Table 1. Characteristics of two kinds membranes used in the research

\begin{tabular}{|l|c|c|}
\hline & \multicolumn{2}{|c|}{ Cut-off $(\mathrm{kDa})$} \\
\hline Parameters & 1.0 & 0.45 \\
\hline Number of channels & 23 & 19 \\
\hline Hydraulic diameter of channel $(\mathrm{mm})$ & 3.5 & 3.5 \\
\hline Membrane diameter $(\mathrm{mm})$ & 25 & 25 \\
\hline Membrane surface $\left(\mathrm{m}^{2}\right)$ & 0.35 & 0.25 \\
\hline Membrane length $(\mathrm{mm})$ & 1178 & 1178 \\
\hline
\end{tabular}

The experimental research was conducted in the two-stage membrane filtration system according to the scheme shown in Figure 2. The filtration process at each stage was conducted in three cycles (duration of an individual cycle $=1 \mathrm{~h}$ ). Between the cycles the membrane was cleaned with distilled water (without returning). Tests were conducted in an open system (i.e. the permeate was reclaimed). The filtration process at both stages was conducted at the constant temperature of $20.0^{\circ} \mathrm{C} \pm 1$ and at the fixed linear velocity of the feed equal to $\mathrm{u}=4 \mathrm{~m} \cdot \mathrm{s}^{-1}$.

At the first filtration stage the membrane with $1.0 \mathrm{kDa}$ cut-off was used. The filtration was conducted using a 3-tube module with total membrane surface of $A_{I}=1.05 \mathrm{~m}^{2}$. The transmembrane pressure equaled $\mathrm{TMP}_{\mathrm{I}}=0.25 \mathrm{MPa}$. The feed $\left(\mathrm{N}_{\mathrm{I}}\right)$ at the 1st filtration stage was the effluent water from intense fish farming.
At the $2^{\text {nd }}$ filtration stage the membrane with $0.45 \mathrm{kDa}$ cut-off was used. The filtration was conducted using a 1-tube module with total membrane surface of $A_{I I}=0.25 \mathrm{~m}^{2}$. The transmembrane pressure equaled $\mathrm{TMP}_{\mathrm{II}}=0.40 \mathrm{MPa}$. The feed $\left(\mathrm{N}_{\mathrm{II}}\right)$ at the $2^{\text {nd }}$ filtration stage was the permeate obtained from the $1^{\text {st }}$ filtration stage $\left(\mathrm{N}_{\mathrm{II}}=\mathrm{P}_{\mathrm{I}}+\mathrm{P}_{\text {II }}+\mathrm{P}_{\text {III }}\right)$ (Fig. 2).

According to methodologies recommended by Standard Methods (1998), selected physico-chemical indicators were measured in the feed, as well as in the permeate $(\mathrm{P})$ and the retentate $(\mathrm{Re})$ collected at hourly intervals. Biological oxygen demand $\left(\mathrm{BOD}_{5}, \mathrm{mgO}_{2} \mathrm{dm}^{-3}\right)$ was determined by a direct method after five day incubation of the samples with no light access at the constant temperature of $20^{\circ} \mathrm{C}$. Chemical oxygen demand $\left(\mathrm{COD}_{\mathrm{Cr}}, \mathrm{mgO}_{2} \mathrm{dm}^{-3}\right)$ was determined by the dichromate method. Suspended solids ( $\mathrm{SS}, \mathrm{mg} \mathrm{dm}^{-3}$ ) were determined by weighing. Nitrite nitrogen $\left(\mathrm{N}^{-\mathrm{NO}_{2}}{ }^{-}, \mathrm{mgN} \mathrm{dm}^{-3}\right)$ was assayed with sulphanyl acid $(\lambda=543 \mathrm{~nm})$. Nitrate nitrogen $\left(\mathrm{N}-\mathrm{NO}_{3}^{-}, \mathrm{mgN} \mathrm{dm}^{-3}\right)$ was determined as nitrite nitrogen after the reduction on a $\mathrm{Cu}-\mathrm{Cd}$ column. Ammonium nitrogen $\left(\mathrm{N}-\mathrm{NH}_{4}^{+}, \mathrm{mgN} \mathrm{dm}^{-3}\right)$ was assayed with indophenol blue $(\lambda=630$ $\mathrm{nm})$. Total inorganic nitrogen ( $\mathrm{TIN}, \mathrm{mgN} \mathrm{dm}^{-3}$ ) was calculated as the sum of nitrite, nitrate, and ammonium nitrogen contents. Total reactive phosphorus (TRP, $\mathrm{mgP} \mathrm{dm}^{-3}$ ) was assayed using the molybdenate technique with ascorbic acid as a reducer $(\lambda=882 \mathrm{~nm})$. Total phosphorus (TP, $\mathrm{mgP} \mathrm{dm}^{-3}$ ) was determined after mineralization with potassium hypersulphate and assayed as TRP. Total iron ( $\left.\mathrm{Fe}, \mathrm{mg} \mathrm{dm}^{-3}\right)$ was determined by phenanthroline $(\lambda=510 \mathrm{~nm})$. The applied calorimetric methods used a spectrophotometer UV-VIS Spectroquant Pharo 300 manufactured by Merck, Germany. Conductivity was measured with a conductivity meter manufactured by Elmetron CC-101, Poland. Turbidity was measured with a turbidimeter manufactured by Eutech Instruments TN-100, Singapore. The water feeding the recirculation system of the aquaculture from which samples were collected for the membrane filtration studies was also tested with respect to its physico-chemical parameters.

After conducting the water purification process, the degree of pollution reduction was measured by calculating the rejection coefficient $\left(\mathrm{R}_{\mathrm{I}}, \mathrm{R}_{\mathrm{II}}, \mathrm{R}_{\mathrm{III}}\right)$. It was calculated for the respective indicators on the basis of analyzing their concentrations in the permeate $\left(\mathrm{CP}_{\mathrm{I}}, \mathrm{CP}_{\mathrm{II}}\right)$ and the feed $(\mathrm{CN})$ according to the formula (1).

$$
\mathrm{R}=(1-\mathrm{CP} / \mathrm{CN}) \times 100 \%
$$

Volumetric of the permeate flux $\left(\mathrm{J}_{\mathrm{V}}, \mathrm{m}^{3} / \mathrm{m}^{2} \mathrm{~s}\right)$ was calculated and the relative membrane permeability was expressed as the $\mathrm{J}_{\mathrm{V}} / \mathrm{J}_{0}$ ratio (where $\mathrm{J}_{\mathrm{V}}=$ permeate flux for the treated water at the $1^{\text {st }}$ and $2^{\text {nd }}$ filtration stage, $J_{0}=$ permeate flux for distilled water).

\section{Results}

The effluent water (EW) from the juvenile African catfish aquaculture was characterized by heightened concentrations of water quality indicators, mainly those important for the life of fish, i.e. $\mathrm{BOD}_{5}, \mathrm{COD}_{\mathrm{Cr}}, \mathrm{SS}$, TIN, and TP. Concentrations of those indicators, in comparison to concentrations found in the feed water, were higher by $594 \%, 2414 \%, 3000 \%, 6670 \%$ and $343 \%$, respectively (Table 2 ). 
Table 2 contains also the requirements of the Polish Minister of Environment's Regulation of 24 July 2006 on wastewater discharge into natural environment. Comparing the values of selected physico-chemical indicators noted in the effluent water with the above mentioned requirements, it was found that substance accretion in the effluent water exceeded acceptable values specified under the Regulation. The values were especially high for such indicators as TIN, $\mathrm{COD}_{\mathrm{Cr}}$, TP and $\mathrm{SS}$, exceeding the norms 25, 21, 9 and 5 times, respectively (Table 2).

The effluent waters, considerably polluted with organic matter and biogenic elements, were used in the treatment process applying membrane filtration; they constituted the feed $\left(\mathrm{N}_{\mathrm{I}}\right)$ at the $1^{\text {st }}$ filtration stage.

Results of permeate quality testing obtained at the $1^{\text {st }}$ filtration stage are compiled in Table 3. The study revealed that already after the first hour of filtration the values of the tested physico-chemical indicators were reduced. The highest degree of retention was obtained for the total suspended solids, turbidity, total iron, $\mathrm{BOD}_{5}$, nitrite nitrogen and $\mathrm{COD}_{\mathrm{Cr}}$. The values of the rejection coefficient $\left(\mathrm{R}_{\mathrm{I}}\right)$ for those indicators equaled: $100.0 \%, 99.4 \%, 89.2 \%, 76.0 \%, 62.3 \%$ and $41.74 \%$, respectively (Tab. 3). The following permeate quality measurements were conducted after two and three hours of filtration; the values of the tested physico-chemical indicators showed a decreasing tendency and thus the degree of rejection of the pollution on the membrane was increasing. Total reduction was noted for the total suspended solids and the total iron content. For the total suspended solids, $100 \%$ rejection was already obtained after the first hour of filtration, whereas for the total iron content the same rejection level was obtained after two hours of filtration. After three hours of filtration a high level of rejection was noted for $\mathrm{COD}_{\mathrm{Cr}}, \mathrm{BOD}_{5}$, nitrite nitrogen and turbidity, with $\mathrm{R}_{\mathrm{II}}$ equal to: $76.81 \%, 96.1 \%, 64.18 \%$, and $99.8 \%$, respectively. The values of the remaining indicators in the retentates decreased only slightly and the rejection coefficient values ranged from $0.17 \%$ (ammonium nitrogen) to $11.67 \%$ (total phosphorus) (Table 3 ).

The results of testing the quality of the permeate obtained at the $2^{\text {nd }}$ filtration stage are given in Table 4. A decreasing tendency was noted with regard to the values of the tested physico-chemical parameters during the filtration process. However, the rejection coefficient values of the studied indicators obtained at that stage were lower than those obtained

Table 2. Characteristics of selected quality indicators of feed water (FW) and effluent water (EW) in the juvenile African catfish aquaculture, substance accretion $(\Delta)$ and substance accretion norms according to the Polish Minister of Environment's Regulation of 24 July 2006

\begin{tabular}{|c|c|c|c|c|}
\hline Water quality index & Feed water FW & Effluent water EW & $\begin{array}{c}\text { Substance accretion } \\
(\Delta)(E W-F W)\end{array}$ & $\begin{array}{c}\text { Requirements } \\
\text { Regulation... 2006 }\end{array}$ \\
\hline $\mathrm{BOD}_{5}$ & 0.86 & 5.11 & 4.25 & 3.0 \\
\hline $\mathrm{COD}_{\mathrm{Cr}}$ & 6.4 & 154.5 & 148.1 & 7.0 \\
\hline $\mathrm{SS}$ & 0.0 & 30.0 & 30.0 & 6.0 \\
\hline TIN & 0.388 & 25.88 & 25.50 & 1.0 \\
\hline TP & 0.389 & 1.336 & 0.947 & 0.1 \\
\hline
\end{tabular}

Table 3. Values of the tested physico-chemical indicators at the $1^{\text {st }}$ filtration stage in the feed $N_{1}$, and measured after 1,2

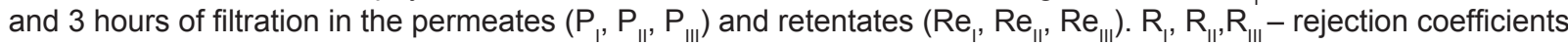

\begin{tabular}{|c|c|c|c|c|c|c|c|c|c|c|}
\hline Water quality index & $\mathrm{N}_{1}$ & $P_{1}$ & $\mathrm{R}_{1}[\%]$ & $\mathrm{P}_{\|}$ & $\mathrm{R}_{\| 1}[\%]$ & $\mathrm{P}_{\text {III }}$ & $\mathrm{R}_{\mathrm{III}}[\%]$ & $\mathrm{Re}_{1}$ & $\operatorname{Re}_{\|}$ & $\mathrm{Re}_{\text {III }}$ \\
\hline $\mathrm{BOD}_{5}\left(\mathrm{mgO}_{2} \mathrm{dm}^{-3}\right)$ & 5.11 & 1.22 & 76.02 & 1.26 & 75.36 & 0.20 & 96.10 & 7.65 & 8.11 & 10.10 \\
\hline $\mathrm{COD}_{\mathrm{Cr}}\left(\mathrm{mgO}_{2} \mathrm{dm}^{-3}\right)$ & 154.51 & 90.20 & 41.74 & 88.16 & 42.94 & 35.82 & 76.81 & 330.37 & 227.82 & 223.86 \\
\hline $\mathrm{SS}\left(\mathrm{mg} \mathrm{dm}^{-3}\right)$ & 30 & 0 & 100 & 0 & 100 & 0 & 100 & 84 & 100 & 118 \\
\hline Turbidity (NTU) & 50.65 & 0.30 & 99.40 & 0.18 & 99.64 & 0.10 & 99.80 & 300.00 & 312.00 & 285.50 \\
\hline Conductivity $\left(\mu \mathrm{S} \mathrm{cm}^{-1}\right)$ & 3151 & 3102 & 1.55 & 3091 & 1.90 & 2841 & 9.86 & 3190 & 3289 & 3622 \\
\hline $\mathrm{N}-\mathrm{NH}_{4}{ }^{+}\left(\mathrm{mgN} \mathrm{dm}^{-3}\right)$ & 0.774 & 0.773 & 0.17 & 0.772 & 0.28 & 0.753 & 2.68 & 0.988 & 0.864 & 0.858 \\
\hline $\mathrm{N}-\mathrm{NO}_{2}^{-}\left(\mathrm{mgN} \mathrm{dm}^{-3}\right)$ & 0.120 & 0.045 & 62.68 & 0.045 & 62.68 & 0.043 & 64.18 & 0.235 & 0.276 & 0.334 \\
\hline $\mathrm{N}-\mathrm{NO}_{3}^{-}\left(\mathrm{mgN} \mathrm{dm}^{-3}\right)$ & 3.270 & 3.246 & 1.63 & 3.188 & 3.38 & 3.054 & 7.46 & 3.370 & 4.074 & 4.404 \\
\hline TIN $(m g N ~ d m ³)$ & 25.88 & 25.39 & 1.91 & 24.09 & 6.95 & 24.05 & 7.10 & 25.57 & 25.38 & 25.39 \\
\hline $\operatorname{TRP}\left(\mathrm{mgP} \mathrm{dm}^{-3}\right)$ & 3.148 & 3.091 & 1.82 & 3.000 & 4.71 & 2.988 & 5.09 & 3.912 & 3.845 & 3.865 \\
\hline $\mathrm{TP}\left(\mathrm{mgP} \mathrm{dm} \mathrm{dm}^{-3}\right)$ & 1.336 & 1.255 & 6.04 & 1.253 & 6.18 & 1.180 & 11.67 & 3.527 & 3.586 & 3.768 \\
\hline Total iron $\left(\mathrm{mgFe} \mathrm{dm}^{-3}\right)$ & 2.313 & 0.251 & 89.17 & 0.00 & 100 & 0.00 & 100 & 5.098 & 5.428 & 5.544 \\
\hline
\end{tabular}


at the 1 st filtration stage. The highest rejection coefficient values at the respective points of time in the course of the filtration process were noted for the total iron $\left(\mathrm{R}_{\mathrm{IV}}=100 \%\right)$, $\operatorname{COD}_{\mathrm{Cr}}\left(\mathrm{R}_{\mathrm{IV}}=59.52 \% ; \mathrm{R}_{\mathrm{V}}=64.28 \%, \mathrm{R}_{\mathrm{VI}}=63.49 \%\right)$ and turbidity $\left(\mathrm{R}_{\mathrm{IV}}, \mathrm{R}_{\mathrm{V}}=45 \%, \mathrm{R}_{\mathrm{VI}}=50.0 \%\right)$. For the remaining indicators concentration reductions at the following points of time during the filtration were comparatively low and rejection coefficients ranged from $\mathrm{R}_{\mathrm{VI}}=0.06 \%$ (ammonium nitrogen) to $\mathrm{R}_{\mathrm{VI}}=21.33 \%$ (nitrate nitrogen) (Table 4.).

During the filtration process, at both filtration stages, it was noted that in the concentrated retentate solution $\left(\mathrm{Re}_{\mathrm{I}}-\mathrm{Re}_{\mathrm{VI}}\right)$ the values of the respective physico-chemical indicators increased, and were especially high for $\mathrm{SS}, \mathrm{BOD}_{5}, \mathrm{COD}_{\mathrm{Cr}}$ and turbidity (Tabs 3 and 4).
Membrane cleaning, conducted hourly during the experimental study, resulted in increasing the efficiency of $\mathrm{Jv}$ at the $1^{\text {st }}$ and the $2^{\text {nd }}$ filtration stage (Fig. 2). Each time, the membrane cleaning lasted for $30 \mathrm{~min}$ and was performed after 60,150 and 240 minutes of the filtration process. Initially, for the 3-tube model applied at the $1^{\text {st }}$ filtration stage, the $\mathrm{Jv}$ dramatically dropped and after ca. $1 \mathrm{~h}$ it was equal to less than $50 \%$ of the original efficiency. Membrane cleaning again increased the efficiency level, with average Jv values growing from 2.7 to $3.65\left(\mathrm{~m}^{3} / \mathrm{m}^{2} \cdot \mathrm{s} \cdot 10^{-5}\right)$. At the $2^{\text {nd }}$ filtration stage the efficiency was much lower and remained at roughly the same level. The cleaning process at that stage also increased the $\mathrm{Jv}$ values, on average from 1.15 to $1.66\left(\mathrm{~m}^{3} / \mathrm{m}^{2} \cdot \mathrm{s} \cdot 10^{-5}\right)$ (Fig. 3).

Table 4. Values of the tested physico-chemical indicators at the $2^{\text {nd }}$ filtration stage in the feed $N_{\|}$, and measured after 1,2 and 3 hours of filtration in the permeates $\left(P_{I V}, P_{V}, P_{V I}\right)$ and retentates $\left(\operatorname{Re}_{I V}, R_{V}, R_{V V}\right) . R_{I V}, R_{V}, R_{V I}-$ rejection coefficients

\begin{tabular}{|c|c|c|c|c|c|c|c|c|c|c|}
\hline Water quality index & $\mathrm{N}_{\|}$ & $P_{I V}$ & $\mathrm{R}_{\mathrm{IV}}[\%]$ & $P_{v}$ & $\mathrm{R}_{\mathrm{v}}[\%]$ & $\mathrm{P}_{\mathrm{VI}}$ & $\mathrm{R}_{\mathrm{vl}}[\%]$ & $\operatorname{Re}_{\mathrm{IV}}$ & $\operatorname{Re}_{v}$ & $\operatorname{Re}_{\mathrm{V}}$ \\
\hline $\mathrm{BOD}_{5}\left(\mathrm{mgO}_{2} \mathrm{dm}^{-3}\right)$ & 1.74 & 1.39 & 20.13 & 1.30 & 25.54 & 1.32 & 24.25 & 2.30 & 2.88 & 3.29 \\
\hline $\mathrm{COD}_{\mathrm{Cr}}\left(\mathrm{mgO}_{2} \mathrm{dm}^{-3}\right)$ & 58.47 & 23.66 & 59.52 & 20.88 & 64.28 & 21.34 & 63.49 & 87.70 & 81.20 & 171.22 \\
\hline Turbidity (NTU) & 0.20 & 0.11 & 45.00 & 0.11 & 45.00 & 0.10 & 50.00 & 1.11 & 0.92 & 0.91 \\
\hline Conductivity $\left(\mu \mathrm{S} \mathrm{cm}^{-1}\right)$ & 2688 & 2600 & 1.51 & 2600 & 1.51 & 2412 & 8.64 & 3036 & 3276 & 3252 \\
\hline $\mathrm{N}-\mathrm{NH}_{4}{ }^{+}\left(\mathrm{mgN} \mathrm{dm}^{-3}\right)$ & 0.719 & 0.718 & 0.12 & 0.718 & 0.12 & 0.718 & 0.06 & 0.753 & 0.760 & 0.771 \\
\hline $\mathrm{N}-\mathrm{NO}_{2}^{-}\left(\mathrm{mgN} \mathrm{dm}^{-3}\right)$ & 0.039 & 0.038 & 1.16 & 0.037 & 1.74 & 0.037 & 2.32 & 0.039 & 0.039 & 0.039 \\
\hline $\mathrm{N}-\mathrm{NO}_{3}^{-}\left(\mathrm{mgN} \mathrm{dm}^{-3}\right)$ & 3.198 & 2.973 & 7.04 & 2.752 & 13.96 & 2.516 & 21.33 & 3.238 & 3.800 & 4.023 \\
\hline TIN $\left(\mathrm{mgN} \mathrm{dm}^{-3}\right)$ & 22.45 & 21.62 & 11.44 & 18.88 & 11.44 & 19.80 & 11.80 & 23.87 & 23.73 & 23.99 \\
\hline $\operatorname{TRP}\left(\mathrm{mgP} \mathrm{dm}^{-3}\right)$ & 1.934 & 1.905 & 1.48 & 1.910 & 1.22 & 1.923 & 0.56 & 1.996 & 1.996 & 2.000 \\
\hline $\mathrm{TP}\left(\mathrm{mgP} \mathrm{dm} \mathrm{d}^{-3}\right)$ & 1.248 & 1.229 & 1.47 & 1.202 & 3.68 & 1.211 & 2.94 & 1.253 & 1.278 & 1.408 \\
\hline Total iron $\left(\mathrm{mgFe} \mathrm{dm}^{-3}\right)$ & 0.017 & 0.0 & 100 & 0.0 & 100 & 0.0 & 100 & 0.038 & 0.042 & 0.046 \\
\hline
\end{tabular}
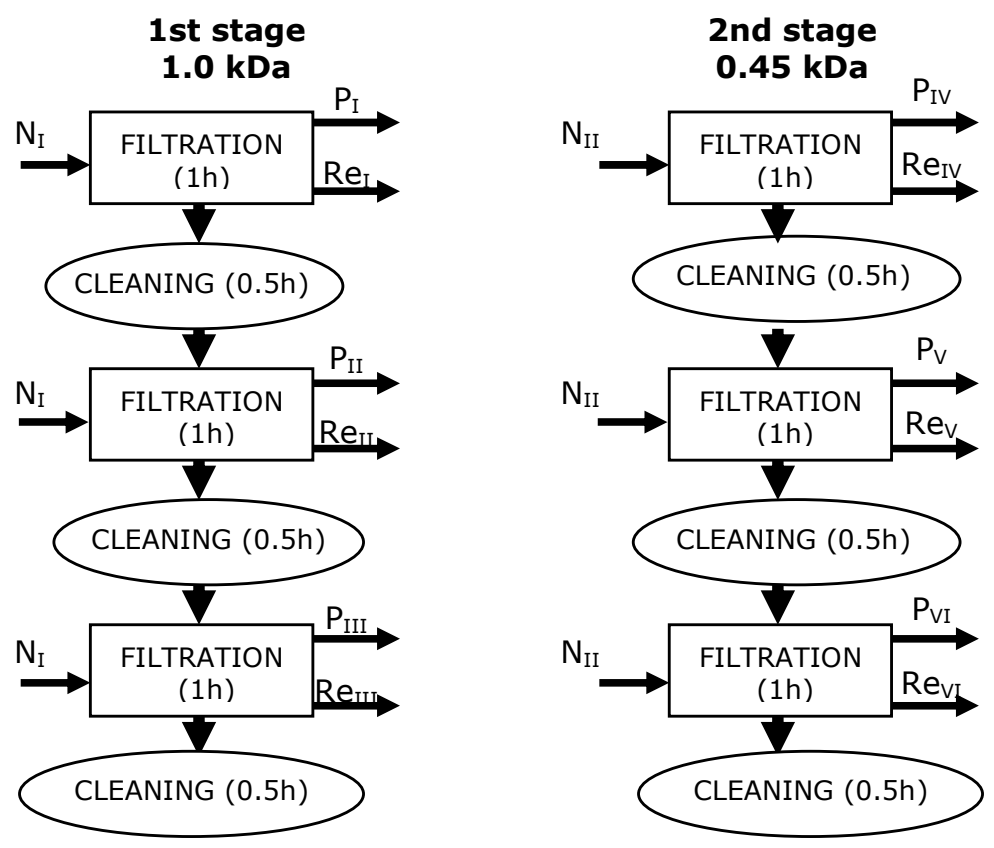

Fig. 2. A block diagram of the conducted experiment featuring the $1^{\text {st }}$ and $2^{\text {nd }}$ filtration stages. $N_{1}-$ feed tank I (effluent water from RAS); $\mathrm{N}_{\|}$- feed tank II (mixed permeates $\mathrm{P}_{\mathrm{I}}, \mathrm{P}_{\|}, \mathrm{P}_{\mathrm{III}}$ from the $1^{\text {st }}$ filtration stage); $\mathrm{Re}_{\mathrm{I}-\mathrm{VI}}-$ retentates 


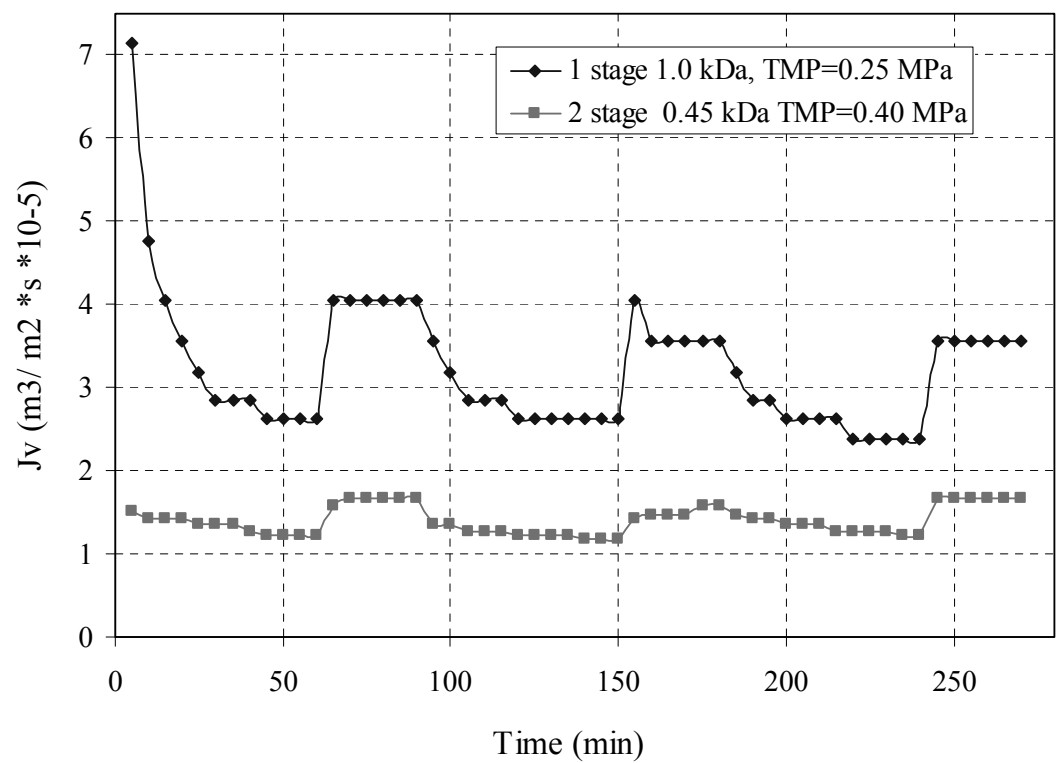

Fig. 3. The relationship between the permeate flux $J v$, and th time and TMP in the two-stage ultrafiltration of effluent water from the juvenile catfish aquaculture

\section{Discussion}

The effluent water from the juvenile African catfish aquaculture was strongly polluted with organic matter and biogenic substances and did not meet the requirements outlined in the Polish Minister of Environment's Regulation of 24 July 2006 on conditions of discharging wastewater into natural waters or into the ground, and on the substances especially harmful to aquatic environment. Therefore, that type of effluent water should undergo an efficient treatment process. In spite of the low water quality in the aquaculture system, the growth and development of the fish was normal. The fish species in question is characterized by a high tolerance for unfavorable environmental conditions (Viveen et al. 1985)

Since the 1990s, the African catfish has been a popular species in Polish fish farms. Its farming is mainly conducted in closed-circulation systems. The fish is thermophilous and omnivorous, and reaches sexual maturity at the age of 6-10 months. A special characteristics of the species is its ability to breathe atmospheric oxygen if it lives in strongly polluted waters with low oxygen content (Viveen et al. 1985). The meat of the catfish is highly valued for its flavor (similar to veal); it has a low fat content and a high total protein content (Nyina-Wamwiza et al. 2007). As the species is not very sensitive to oxygen deficits and pollution, it is possible to use water of inferior quality in its farming. At the same time, breeding and farming of the African catfish are very intensive and generate strongly polluted wastewater. This fact, in light of striving for sustainable aquaculture which aims to maintain natural resources in the best possible condition while producing food, implies the necessity to develop and introduce in practice such farming techniques that will minimize its negative impact on the environment. One of possible solutions is the implementation of RAS, using various methods for effluent water treatment (Martins et al. 2010). Recirculation systems, commonly applied for fish breeding and farming, are based on mechanical (filters, sedimentation tanks), biological (trickling filters), or chemical water purification and finally, its disinfection (UV radiation, ozonization) (Yang et al. 2006, Singer et al. 2008, Van Rijn 2013).

The studies on applying membrane separation techniques in treatment systems are a recent trend (Viadero and Noblet 2002, Gemende et al. 2008, Harvianto et al. 2013, Yang et al. 2006). Gemende et al. (2008) applied capillary polymer membranes in recirculation systems in order to minimize water consumption while maintaining safe concentrations of nitrogen associations and suspensions. The applied membranes totally eliminated the suspended solids and decreased the biomass content to the level enabling further processing by fermentation. Viadero and Noblet (2002) also applied polymer filtration membranes in RAS and obtained a high retention of $\mathrm{BOD}_{5}$ and $\mathrm{COD}_{\mathrm{Cr}}$, at the level of $71 \%$ and $67 \%$ respectively. Furthermore, Bonisławska et al. (2010) tested the possibility of applying modern third-generation ceramic membranes in the one-stage process of eliminating pollution from the water discharged by fish hatcheries, pointing to the possibility of its recirculation. Another study tested a two-stage process of treating water from a fish hatchery (3-tube module at the $1^{\text {st }}$ stage; 1-tube module at the $2^{\text {nd }}$ stage) using ceramic membranes with $1.0 \mathrm{kDa}$ cut-off. That system allowed for eliminating from the water $100 \%$ of total suspended solids, $93 \%$ of $\mathrm{COD}_{\mathrm{Cr}}$ and $73 \%$ of $\mathrm{BOD}_{5}$ Szaniawska et al. 2011. Similarly, Fu et al. (1995) and Yang et al. (2006) obtained high rejection coefficient values for turbidity: $84.0-89.2 \%$ and $86.5 \%$ respectively. Furthermore, Yang et al. (2006) applied a hybrid system (combining polymer microfiltration membranes with chemical precipitation) and obtained even better results (98.0-99.9\%). Orecki and Tomaszewska (2004), purifying lake water with an NF-270 nanofiltration polymer membrane obtained the retention level of $85.9 \%$ for $\mathrm{COD}_{\mathrm{Cr}}$.

The present studies allowed for obtaining a similar rejection level of the tested indicators already at the $1^{\text {st }}$ filtration stage. A high efficiency of the applied ceramic membranes was also noted for iron elimination. The $2^{\text {nd }}$ 
filtration stage resulted in a further drop in the values of the analyzed physico-chemical indicators, but to a lesser extent. The differences are explicable by differences in qualitative composition of the feed. At the $1^{\text {st }}$ stage, effluent water from the juvenile African sharptooth catfish aquaculture was the feed $\left(\mathrm{N}_{\mathrm{I}}\right)$, whereas at the $2^{\text {nd }}$ stage the permeate obtained after the 1 st stage filtration was the feed $\left(\mathrm{N}_{\mathrm{II}}=\mathrm{P}_{\mathrm{I}}+\mathrm{P}_{\text {II }}+\mathrm{P}_{\text {III }}\right)$. The differences in qualitative composition of the feed determined also the phenomenon of membrane fouling, which shall be discussed below. Similar differences in the rejection levels in the two-stage filtration process were also noted by Szmukała and Szaniawska (2009), who compared the performance of ceramic membranes with different cut-offs in two-stage systems. In their study, the 1st stage involved the filtration through a membrane with the $1.0 \mathrm{kDa}$ cut-off, and rejection coefficients for $\mathrm{BOD}_{5}$ and $\mathrm{COD}_{\mathrm{Cr}}$ ranged between $89-92 \%$ and $45-33 \%$ respectively. At the $2^{\text {nd }}$ filtration stage the authors tested a membrane with the $3.0 \mathrm{kDa}$ cut-off, and rejection coefficients for $\mathrm{BOD}_{5}$ and $\mathrm{COD}_{\mathrm{Cr}}$ ranged between $49-68 \%$ and $24-35 \%$ respectively.

Furthermore, low rejection coefficients for $\mathrm{N}-\mathrm{NH}_{4}^{+}$, $\mathrm{N}-\mathrm{NO}_{3}^{-}, \mathrm{N}-\mathrm{NO}_{2}^{-}$, TIN, TRP, and TP should be pointed out. Similar results were obtained e.g. by Yang et al. (2006), Bonisławska et al. (2010) and Szaniawska et al. (2011). In the present study, among that group of indicators, the highest rejection was noted for nitrate nitrogen (at the $1^{\text {st }}$ filtration stage the rejection coefficient equaled $62.3-64.18 \%$ ). The results were concurrent with those obtained by Van der Bruggena et al. (2001, 2002), who noted a wide range of nitrate elimination: from 16.0 to $76.0 \%$, depending on the type of applied nanofiltration membrane. For the ammonium nitrogen, the rejection level was up to $21 \%$. The present result was similar to that obtained by Waniek (2006), i.e. $24 \%$, however, in that author's study polymer membranes were used.

Efficiency of the process of membrane separation depends on the molecular mass of the filtered substance. For instance, Kabsch-Korbutowicz et al. (2009) studied the efficiency of separation for substances with various molecular masses on a ceramic membrane with $50.0 \mathrm{kDa}$ cut-off. They observed that regardless of the transmembrane pressure, $95-100 \%$ of substances with greater molecular mass were retained, while the efficiency of eliminating substances with molecular mass within the range 327-466 Da was lower and depended on the transmembrane pressure. They also noted that as the pressure increased, the efficiency of separation deteriorated for substances with low molecular mass; it may be explained by the fact that a pressure increase causes an increase in membrane permeability and an increasing number of small molecules diffuse across the membrane.

Similar relationships were noted in the present study. A membrane with a smaller cut-off $(0.45 \mathrm{kDa})$ and a higher transmembrane pressure were applied at the $2^{\text {nd }}$ filtration stage than at the $1^{\text {st }}$ filtration stage. Under such filtration conditions, the rejection coefficient for analyzed physicochemical indicators was lower at the $2^{\text {nd }}$ filtration stage than at the $1^{\text {st }}$ filtration stage. The results pointed out that at the $2^{\text {nd }}$ filtration stage the substances with lower molecular masses were more likely to diffuse across the membrane (biogenic substance concentrations were not subject to considerable reductions).
An important phenomenon in membrane separation processes is the phenomenon of fouling connected with gradual blocking of membrane pores (irreversible fouling) and the development of a filter on its surface (reversible fouling). The phenomenon acts as an additional filter, contributing to the occurrence of hydraulic resistance and decreasing the volume of permeate flux over time (Mohammad et al. 2012, Luo and Wan 2013). The permeate flow decreases quickly during the first 10-15 minutes of filtration and then achieves a quasi-steady state value after ca. 30-40 minutes (Viadero and Noblet 2002). A similar decrease of the permeate flow was also noted in the present study at the $1^{\text {st }}$ filtration stage. However, at the $2^{\text {nd }}$ filtration stage the permeate flow decreased only slightly over time. The results indicated that at the latter stage fouling was lower than at the $1^{\text {st }}$ stage.

Cyclic membrane cleaning with deionized water increased membrane efficiency, but did not make it as efficient as at the beginning of the experiment. The results of the studies showed that a drop in the membrane efficiency level at both filtration stages was caused by the phenomena of reversible and irreversible fouling, typical for membrane separation processes. At the same time, at the $1^{\text {st }}$ filtration stage each following membrane cleaning cycle restored a lower level of membrane efficiency, which pointed to the increasing role of irreversible fouling in the reduction of the permeate flux volume.

Membrane blockage is one of the most serious exploitation problems connected with the processes of micro- and ultrafiltration. Even though ceramic membranes are strongly hydrophilous, they are blocked mainly by organic substances present in water (Verweij 2003). The effluent water used in the present study as the feed at the 1st filtration stage was rich in organic matter (both dissolved and in the total solution), which should be considered as a major factor contributing to the occurrence of fouling. The feed at the $2^{\text {nd }}$ filtration stage was characterized by lower $\mathrm{COD}_{\mathrm{Cr}}$ and $\mathrm{BOD}_{5}$ concentrations as well as the absence of total suspended solids. Thus, the fouling phenomenon was less intense and the efficiency of the permeate flux volume remained roughly the same over time.

\section{Conclusions}

The results of the conducted studies using ceramic membranes (with 1.0 and $0.45 \mathrm{kDa}$ cut-offs) showed that such membranes may be used in recirculation systems of aquacultures as one of the stages of effluent water purification. The studied membrane system proved excellent for eliminating organic matter from the effluent water. However, due to a comparatively low reduction of dissolved nitrogen and phosphorus forms, such a membrane system may function as an element of a hybrid system in which the respective stages of effluent water purification contribute to decreasing biogenic element concentrations. Another element of such a hybrid system might be an aquaponics system, in which plants intensely absorb N and P. Developing a hybrid system composed of a pressure membrane separation system and aquaponics may provide an attractive alternative for classical, complicated purification systems that are presently applied in intensive aquaculture. 


\section{References}

Bonisławska, M., Szaniawska, D. \& Kuca, M. (2010). Studies on ceramic membrane application for the treatment of effluent water from fish hatcheries, Monographies of the Environmental Engineering Committee of the Polish Academy of Sciences "Membranes and membrane process in environmental protection”, 6, pp. 77-85. (in Polish)

Davidson, J., Good, C., Barrows, F.T., Welsh, C., Kenney P.B. \& Summerfelt, S.T. (2013). Comparing the effects of feeding a grainor a fish meal-based diet on water quality waste production and rainbow trout Oncorhynchus mykiss performance within low exchange water recirculating aquaculture systems, Aquacultural Engineering, 52, pp. 45-57.

Fu, P., Ruiz H., Lozier, J., Thompson, K. \& Spangenberg, C. (1995). A pilot study on groundwater natural organics removal by low-pressure membranes, Desalination, 102, pp. 47-56.

Gemende, B., Gerbeth, A., Pausch, N. \& Bresinsky, A. (2008). Tests for the application of membrane technology in a new method for intensive aquaculture, Desalination, 224, pp. 57-63.

Good, C., Davidson, J., Welsh, C., Brazil, B., Snekvik, K. \& Summerfelt, S. (2009). The impact of water exchange rate on the health and performance of rainbow trout Oncorhynchus mykiss in recirculation aquaculture systems, Aquaculture, 294, pp. 80-85.

Harvianto, G.R., Widiasa, I.N. \& Susanto, H. (2013). Removal organic contaminants on aquaculture using ultrafiltration membranes, Indonesian Scholars Journal, 1 (1), pp. 33-38.

Kabsch-Korbutowicz, M. \& Urbanowska, A. (2010). Water treatment in integrated process using ceramic membrane, Polish Journal of Environmental Studies, 4 (19), pp. 731-737.

Kabsch-Korbutowicz, M., Urbanowska, A., Majewska-Nowak, K. \& Kawiecka-Skowron, J. (2010). Ceramic ultrafiltration membrane application for elimination of organic substances from water solutions, Annual Set The Environment Protection, 12, pp. 467-478. (in Polish)

Luo, J. \& Wan, Y. (2013). Effect of pH and salt on nanofiltration - a critical review, Journal of Membrane Science, 438, pp. 18-28.

Martins, C.I.M., Pistrin, M.G., Ende, S.W., Eding, H. \& Verreth, J.A.J. (2009). The accumulation of substances in Recirculating Aquaculture Systems (RAS). Affects embryonic and larval development in common carp Cyprinus carpio, Aquaculture, 291, pp. 65-73.

Martins, C.I.M., Eding, H., Verdegema, M.C.J., Heinsbroeka, L.T.N., Schneiderc, O., Blanchetond, J.P., Roque d'Orbcasteld, E. \& Verreth, J.A.J. (2010). New developments in recirculating aquaculture systems in Europe: A perspective on environmental sustainability, Aquacultural Engineering, 43, (3), pp. 83-93.

Matsushita, T., Matsui, Y., Shirasaki, N. \& Kato, Y. (2005). Effect of membrane pore size, coagulation time, and coagulant dose on virus removal by a coagulation-ceramic microfiltration hybrid system, Desalination, 178, pp. 21-26.

Mohammad, A.W., Ng, C.Y., Lim, Y.P. \& Ng, G.H. (2012). Ultrafiltration in food processing industry: Review on application, membrane fouling and fouling control, Food Bioprocess Tech., 5, (4), pp. 1143-1156.

Nyina-Wamwiza, L., Wathelet, B. \& Kestemont, P. (2007). Potential of local agricultural by-products for the rearing of African catfish Clarias gariepinus in Rwanda: effects on growth, feed utilization and body composition, Aquaculture Research, 38, (2), pp. 206-214.
Orecki, A., Tomaszewska, M., Karakumski, K. \& Morawski, A.W. (2004). Surface water treatment by the nanofiltration metod, Desalination, 162, pp. 47-54.

Rosenthal, H. \& Hilge, V. (1992). Fish farm effluents and their control in EC countries, FAR Workshop, Hamburg 23-25 Nov. 1992, Hamburg. Inst. für Meereskunde.

Schneider, O., Sereti, V., Endig, H., Verreth, J.A.J. \& Klapwijk, B. (2007). Kinetics, design and biomass production of a bacteria reactor treating RAS effluent streams, Aquacultural Engineering, 36, pp. 24-35.

Singer, A., Parnes, S, Gross, A., Sagi, A. \& Brenner, A. (2008). A novel approach to denitrification processes in a zero-discharge recirculating system for small-scale urban aquaculture, Aquacultural Engineering, 39, pp. 72-77.

Sondhi, R., Bhave, R. \& Jung, G. (2003). Applications and benefits of ceramic membranes, Membrane Technology, 11, pp. 5-8.

Standard Methods for Examination of Water and Wastewater (1998). American Public Health Association APHA, Washington 1998.

Szaniawska, D., Bonisławska, M., Ćwirko, K. \& Worobec, M. (2011). Studies on the degree of permeate recovery in a two-stage system for treating effluent water from fish hatcheries applying non-organic membranes, Chemical Engineering and Equipment, 5, pp. 104-105. (in Polish)

Szmukała, M. \& Szaniawska, D. (2009). Application of ceramic membranes in water treatment for fish hatchery supplying purposes, Desalination, 240, pp. 117-126.

Van der Burggen, B., Everaert, K., Wilms, D. \& Vandecasteele, C. (2001). Application of nanofiltration for removal of pesticides, nitrate and hardness from ground water: rejection properties and economic evaluation, Journal of Membrane Science, 193,(2), pp. 239-248.

Van der Burggen, B. \& Vandecasteele, C. (2002). Distillation vs. membrane filtration overview of process evaluations in seawater, Desalination, 143, pp. 207-218.

Van Rijn, J. (2013). Waste treatment in recirculating aquaculture systems, Aquacultural Engineering, 53, pp. 49-56.

Verweij, H. (2003). Ceramic membranes: Morphology and Transport, Journal of Material Science, 38, pp. 4677-4695.

Viadero, R.C.Jr. \& Noblet, J.A. (2002). Membrane filtration for removal of fine solids from aquaculture process, Aquacultural Engineering., 26, pp. 151-169.

Viveen, W.J., Richter, C.J., Janssen, J.A., van Oordt, P.G. \& Huisman, E.A. (1985). Practical manual for the culture of the African catfish (Clarias gariepinus). International Cooperation of the Ministry of Foreign Affairs, Netherlands. Department of Fish Culture and Fisheries of the Agricultural University of Wageningen, Netherlands and Comparative Endocrinology, Department of Zoology of the University of Utretch, the Netherlands, p. 94.

Waniek, A. (2006). Evaluation of natural water treatment efficiency applying reverse osmosis, nanofiltration and ultrafiltration, in: Membranes and membrane processes in environmental protection. Monographies of the Environmental Engineering Committee of the Polish Academy of Sciences, 36, pp. 661-669. (in Polish)

Yang, L., Zhou, H. \& Moccia, R. (2006). Membrane filtration coupled with chemical precipitation to treat recirculating aquaculture system effluents, Journal of Environmental Quality, 35, pp. 2419-2424

Yonnekawa, H., Tomita, Y. \& Watanabe, Y. (2004). Behavior of macroparticles in monolith ceramic membrane filtration with pre-treatment, Water Science \& Technology, 50, (12), pp. 317-325. 


\section{Zastosowanie membran ceramicznych do oczyszczania wód poprodukcyjnych z hodowli ryb w obiegach zamkniętych}

Streszczenie: Celem pracy była analiza i ocena możliwości wykorzystania dwustopniowego systemu filtrowania z zastosowaniem membran ceramicznych w postaci modułu 3 rurowego o granicznej rozdzielczości membrany (z ang. cut-off) wynoszącej $1.0 \mathrm{kDa}$ (I stopień) i modułu jednorurowego o granicznej rozdzielczości membrany wynoszącej $0.45 \mathrm{kDa}$ (II stopień), do procesu oczyszczania wód poprodukcyjnych pochodzących z hodowli narybku suma afrykańskiego. Podczas I stopnia procesu filtracji wody poprodukcyjnej badania wykazały, że W najwyższym stopniu zatrzymywane były: zawiesina ogólna $\mathrm{SS}-\mathrm{R}_{\mathrm{I}}=100,0 \%$, mętność $\mathrm{R}_{\mathrm{I}}=99.40 \%$, zawartość żelaza ogólnego $\mathrm{R}_{\mathrm{I}}=89.20 \%, \mathrm{BZT}_{5} \mathrm{R}_{\mathrm{I}}=76.0 \%$, oraz azot azotynowy $\mathrm{R}_{\mathrm{I}}=62.30 \%$ i ChZT $\mathrm{Cr}_{\mathrm{I}}=41.74 \%$. II stopień procesu filtracji powodował mniejszy stopień redukcji wartości badanych wskaźników niż I stopień procesu filtracji. Wówczas najwyższy współczynnik retencji odnotowano w przypadku zawartości żelaza ogólnego $\mathrm{R}_{\mathrm{IV}}=100 \%$, $\mathrm{COD}_{\mathrm{Cr}} \mathrm{R}_{\mathrm{IV}}=59.52 \% ; \mathrm{R}_{\mathrm{V}}=64.28 \%, \mathrm{R}_{\mathrm{VI}}=63.49 \%$ i mętności $\mathrm{R}_{\mathrm{IV}}$ i $\mathrm{R}_{\mathrm{V}}=45.0 \%, \mathrm{R}_{\mathrm{VI}}=50.0 \%$.

Uzyskane wyniki wskazują na możliwość wykorzystania membran ceramicznych (o cut-off 1.0 i $0.45 \mathrm{kDa}$ ) w recyrkulacyjnych systemach akwakultury, jako jeden z etapów oczyszczania wód poprodukcyjnych. 